\title{
Resenha
}

\section{Direito e literatura: os verbos auxiliares do coração, ou os significados que tudo possa ter em Péter Esterházy}

\author{
Law and Literature:The auxiliary verbs of the heart, \\ or the meanings that everything may have in Péter Esterházy
}

\author{
Luiz Gonzaga Silva Adolfo' \\ Universidade de Santa Cruz do Sul, Brasil \\ Universidade Luterana do Brasil, Brasil \\ gonzagaadolfo@yahoo.com.br
}

ESTERHÁZY, P. 20I I. Os verbos auxiliares do coração. São Paulo, Cosac Naify, 72 p.

\begin{abstract}
"Existe sempre alguma coisa ausente que me atormenta"

(Da escultora Camille Claudel, para seu mestre e amante, Auguste Rodin, em 1886).
\end{abstract}

Para começar, permitam-me uma breve explicação e, logo após, uma apresentação também sucinta do autor resenhado. Para quem, em dez anos consecutivos, fez mestrado e doutorado em Direito na Unisinos, e assim tinha concentração exacerbada em obras jurídicas, era muito difícil aceitar a realidade de pouco ler literatura de ficção. Especialmente, quem trabalha com os Direitos Autorais, como eu, e desde a infância se acostumou a "devorar" livros, os que tínhamos disponíveis nas escolas públicas da década de 1970, como a obra inteira de Érico Veríssimo, não pode ficar à margem da literatura. Tive um bom começo. Nos últimos seis anos pós-doutorado, procurei recuperar o tempo de abstinência com leituras como Zorro, de Isabel Allende, ou Travessuras de menina má, de Mário Vargas Llosa, e $O$ Primeiro ano: como se faz um advogado, de Scott Thurow.

Aquelas que falam de linguagem, ou do sentido das palavras em viés semiótico, sempre me chamam a atenção. $\mathrm{Na}$ condição de professor de Hermenêutica Jurídica, aprecio de forma singular livros e outros escritos que por aí "deslizam". Tanto que já encomendei, no pré-lançamento, o novo livro de Umberto Eco, $O$ cemitério de Praga, tido pela crítica como seu melhor livro após $O$ nome da rosa, e olhem que não me esqueço de Baudolino.

Nesta perspectiva, este livro de Péter Esterházy (quem fala, como já foi observado, não é um docente da área das Letras em sentido estrito), um autor pouco conhecido no Brasil, ao que tudo indica, foi verdadeiramente "um achado". Esterházy nasceu em Budapeste, em 1950, é conhecido como um "renovador da linguagem do romance", tem mais de 30 livros publicados, foi traduzido para mais de 25 idiomas e ganhou cerca de 20 prêmios literários.

Já é o suficiente.Vamos à obra.

Começar um livro com epígrafe, citando filósofo do porte de Ludwig Wittgenstein ("Pode falar quem tem esperança, e vice-versa"), já estimula à descoberta da obra logo no início do percurso. O mesmo pode-se dizer no também incomum prefácio em obras literárias de ficção, como se vê na página 9:

I Advogado, Mestre e Doutor em Direito pela Unisinos. Professor do PPG em Direito da Universidade de Santa Cruz do Sul, Av. Independência, 2293, Prédio 53, Bairro Universitário, 96815-900, Santa Cruz do Sul, RS, Brasil, e professor do Curso de Direito da Universidade Luterana do Brasil, Av. Itacolomi, 3600 , São Vicente, 94155-052, Gravataí, RS, Brasil. 
Não uso a língua, não quero descobrir a verdade, e menos ainda expô-la diante dos senhores. Também não me ocorre nomear o mundo, e, consequentemente, não nomeio coisa alguma, pois nomear é o mesmo que sacrificar para sempre o nome à coisa nomeada...

Nessa parte introdutória, o personagem central refere o ponto nevrálgico da narrativa:"faz quatro semanas que mamãe morreu...”, e por aí vai.

Penso que seja incomum também, entre tantas coisas pouco recorrentes e boas que se visualizam no romance aqui focado, escrever livro de ficção no qual, ao final de cada página, haja um pensamento: alguns curtos; outros mais longos, pertinentes ou não, mas todos profundamente apropriados e induzidores de reflexão. $E$ sempre em letras maiúsculas. Eis alguns exemplos deles:

“VOCÊ EXISTE PARA SER" (p. 32).

"AQUELA MUDANÇA ERA A PRIMEIRA DE UMA SÉRIE INFINITA. PODERÁ MUDAR O UNIVERSO" (P. 35).

“NEGAMOS COMVERBOS AUXILIARES” (p. 39).

“ESTE É UM MUNDO QUEAFIRMA POSSUIR HONRA, EMBORA SEJA BEM EVIDENTE QUE NÃO POSSUI HONRA" (p. 40).

"NUNCA PODEMOS DIZER A VERDADE, PARA NINGUÉM E SOBRE NADA, PORQUE NESTE PAÍS SÓ A MENTIRA FUNCIONA" (p. 40).

"AS MULTIDÕES OU OSTRIBUNAIS DECIDEM QUEM DEVE SER PUNIDO OU RIDICULARIZADO” (p. 40).

"CHEGA DE PERDER TEMPO NA VIDA.TODOS OS DIAS DE MANHÃ, ANOTE O SEU SONHO" (p. 42).

"ESCREVO NA TERCEIRA PESSOA DO SINGULAR, ASSIM ME SINTO SEGURO, ESPERO NÃO MORRER LOGO” (p. 43).

E ainda, no permeio de sua densa narrativa e da complexidade dos personagens, encontram-se frases fortes, como as três que se enfatizam de dezenas delas:

"Enquanto não houver problema, não há problema, só existe um problema quando há um problema" (p. II).

"Nem a morte, nem seu dono, que é Deus, nos leva a sério. Podemos ter uma resposta, digna de um ser humano. É só não os levarmos a sério também" (p. 17).
"Não tenho liberdade, não escrevo o que quero, mas o que suporto, o que a frase permite" (p.43).

Em meio às referências a um périplo de autores da língua húngara com nomes repletos de consoantes e, alguns deles, com acentos que soam indevidos, o narrador conta, colocando em cena personagens "quase sem nome", a difícil situação da doença terminal da mãe, a visita ao hospital acompanhado do pai com o qual pela primeira vez conseguiu falar de amor, ainda na presença da irmã e do irmão. Denuncia detalhes da casa de saúde, a ideia de vazio existencial, o silêncio perturbador de todos entre um e outro devaneio de pacientes possivelmente em instantes finais, o interesse vivo na enfermeira com seu uniforme excitador, os tantos pensamentos e memórias bons, maus e nem tanto um ou outro que sempre nos acorrem nos longos e intermináveis instantes de um velório de ente querido.

Tudo acontece num relato complexo, chamando a atenção viva e redobrada do leitor, que não consegue interromper a leitura sem antes chegar ao final. $E$ esse, ele o quer logo.

Mas uma mudança radical anuncia o que vem no segundo momento da instigante narrativa. Após uma página central apresentada na cor preta com uma frase em branco ao centro ("Sou um metal que ressoa e um címbalo vibrante"), a segunda fase na obra navega por inusitada inversão: agora é a mãe que sepulta seu filho.

Nesta derradeira parte, a narrativa continua forte e marcante. A mãe se diz nem alegre nem triste pela morte do filho, mas, simplesmente, sem vontade alguma, restando-lhe somente a dor, "apesar de tudo". Relembra histórias de sua formação, minúcias do convívio familiar, os detalhes das árvores do parque, a missa que tinha seu início com um pai-nosso enunciado pelas crianças. Recorda também pormenores nobres e outros nem tão grandiosos do relacionamento com o pai de seu filho a quem dirige palavras.

Ali, para não destoar do restante do texto, aparecem, mais uma vez, vários dos sentimentos e toda a contradição humana. A perda, a dor, a culpa, a (des)esperança. As idas e vindas da existência, o engordar, o emagrecer. Tudo é impar, contraditoriamente, com leve toque de excêntrico.

Antes de concluir sua criação com um lacônico "Fim", no início de uma página que fica vazia em toda a sua extensão central até terminar com a frase "um dia vou escrever isso tudo com mais precisão", Esterházy afirma, de forma quase definitiva, que "tudo tem significado" (p. 47). 
Tem razão, se as convenções humanas de todo naipe nos comprovam, diuturnamente, a configuração nos sentidos de significante/significado; possivelmente, poucas vezes se viu, de forma tão concreta, nas artes em geral e na música e na literatura em particular, como as palavras (no início era o verbo, antes do mundo físico...) assumem verdadeiramente seu lugar no universo.
Com o perdão da ousadia de pretenso escriba em publicação científica da área literária, percebo em todos os personagens coisas ausentes e profundamente perturbadoras. É a convicção de que, em torno do coração, nada é auxiliar, ali tudo é essencial...

Vale a leitura! O leitor vai sair com mais dúvidas e humanamente mais rico, e isso já é tudo... 